\title{
Athetis hospes (Freyer, 1831) Nyugat-Magyarországon (Lepidoptera: Noctuidae)
}

\author{
SZEŐKe KÁLMÁN ${ }^{1} \&$ AvAR KÁLMÁN ${ }^{2}$ \\ ${ }^{1}$ H-8000 Székesfehérvár, Táncsics Mihály u. 4. 1/8 e-mail: szeokek@gmail.com \\ ${ }^{2}$ H-9739. Nemescsó, Péterfy u. 33. e-mail: avarne54@gmail.com
}

SzeöKe, K. \& Avar, K.: Athetis hopses (Freyer, 1831) from Western Hungary (Lepidoptera: Noctuidae). Abstract: One specimen of the Western Palaearctic, mediterranean distributed species Athetis hospes (Freyer, 1831) was captured by a light trap in Oszkó, Western Hungary, on 6th of October, 2018. It is a new record for the Hungarian fauna. The species is spreading most likely from the Croatian and Slovenian seashore. Because of climate change and temperature rise, its presence is possible in other parts of Hungary, but stable population is highly questionable.

Keywords: Athetis hospes, Lepidoptera, faunistics, new record, Western Hungary

\section{Bevezetés}

Az Athetis (Proxenus) hospes (Freyer, 1831) (1. és 2. ábra) a Noctuidae lepkecsalád Xyleninae alcsaládjába tartozik. A meglehetősen gazdag, 148 fajt felölelö Athetis nemzetséget Európában csupán 5 faj képviseli. Ebből 4 faj (A. gluteosa (Treitschke, 1835), A. furvula (Hübner, 1808), A. pallustris (Hübner, 1808), A. lepigone (Möschler, 1860)) Magyarországon is elterjedt. Ám, a föként a mediterráneumból ismert Athetis hospes (Freyer, 1831) magyarországi előfordulását eddig még nem észleltük (Kovács, 1953, 1956, Varga et al., 2004, Pastoralis, Buschmann \& Ronkay, 2016).

\section{Anyag és módszer}

A Vas megyében, Vasvár közelében, Oszkón működő növényvédelmi fénycsapda 2018. október 6-án egy nőstény Athetis hospes (Freyer, 1831) példányt fogott (3. ábra). A lepke genitália vizsgálatát Ronkay László végezte el (4. ábra).

\section{Eredmények}

A faj európai előfordulását a múlt század elején ABAFI (1907), SPULER (1910), WARREN (1914) is tárgyalták. Teljeskörü elterjedését KARSHOLT \& RAZOwsKi (1996), majd FIBIGER \& HACKER (2008) ismertetik. Ismereteink szerint e nyugat-palearktikus 


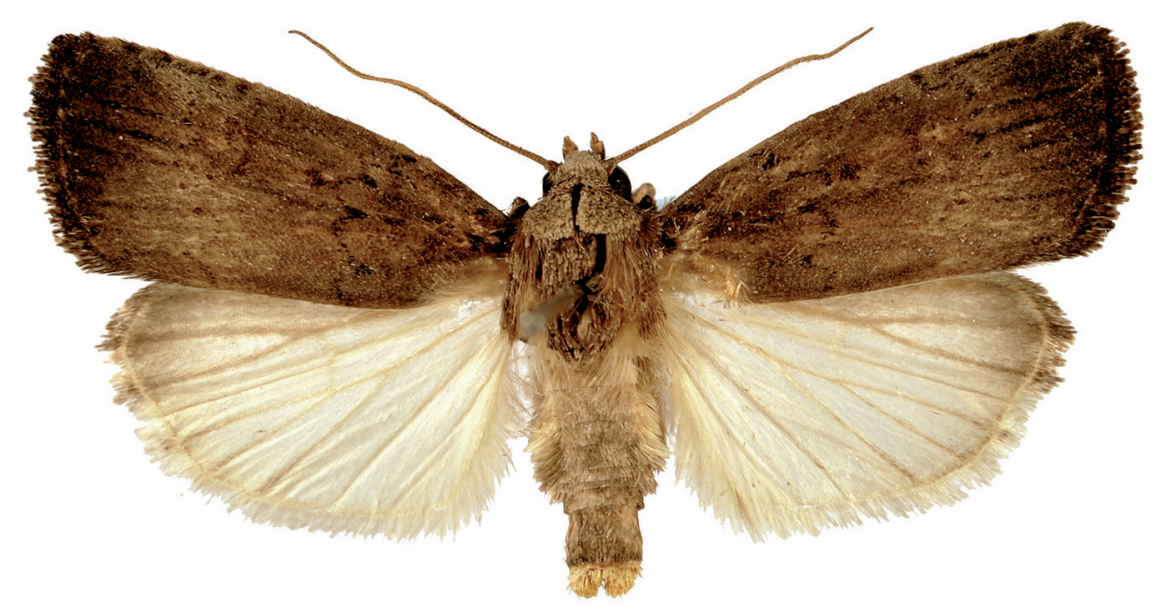

1. ábra: Athetis hospes hím példány, Görögország (Fotó Ronkay Gábor)

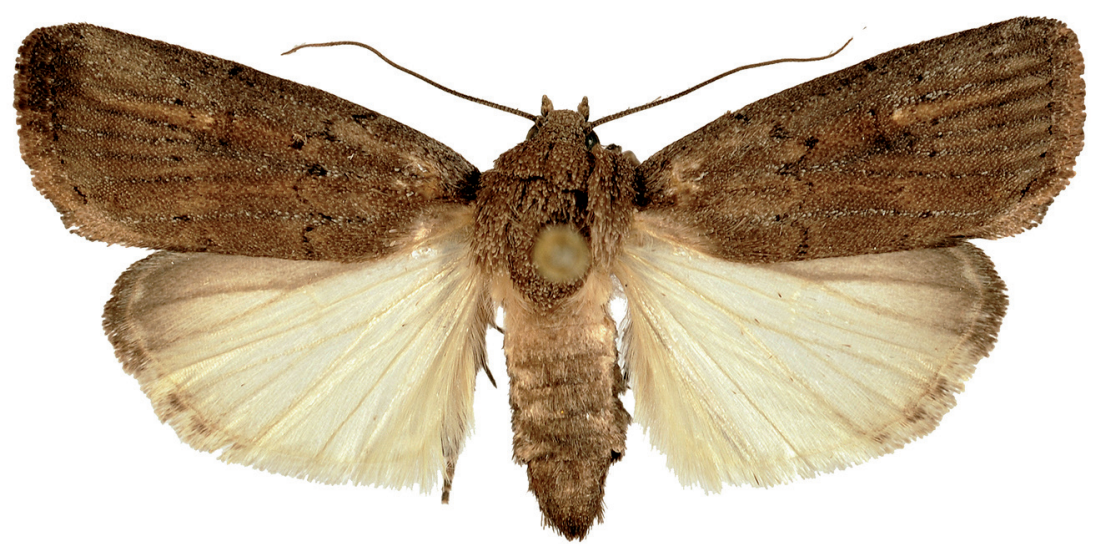

2. ábra: Athetis hospes nőstény példány, Olaszország (Fotó Ronkay Gábor) 


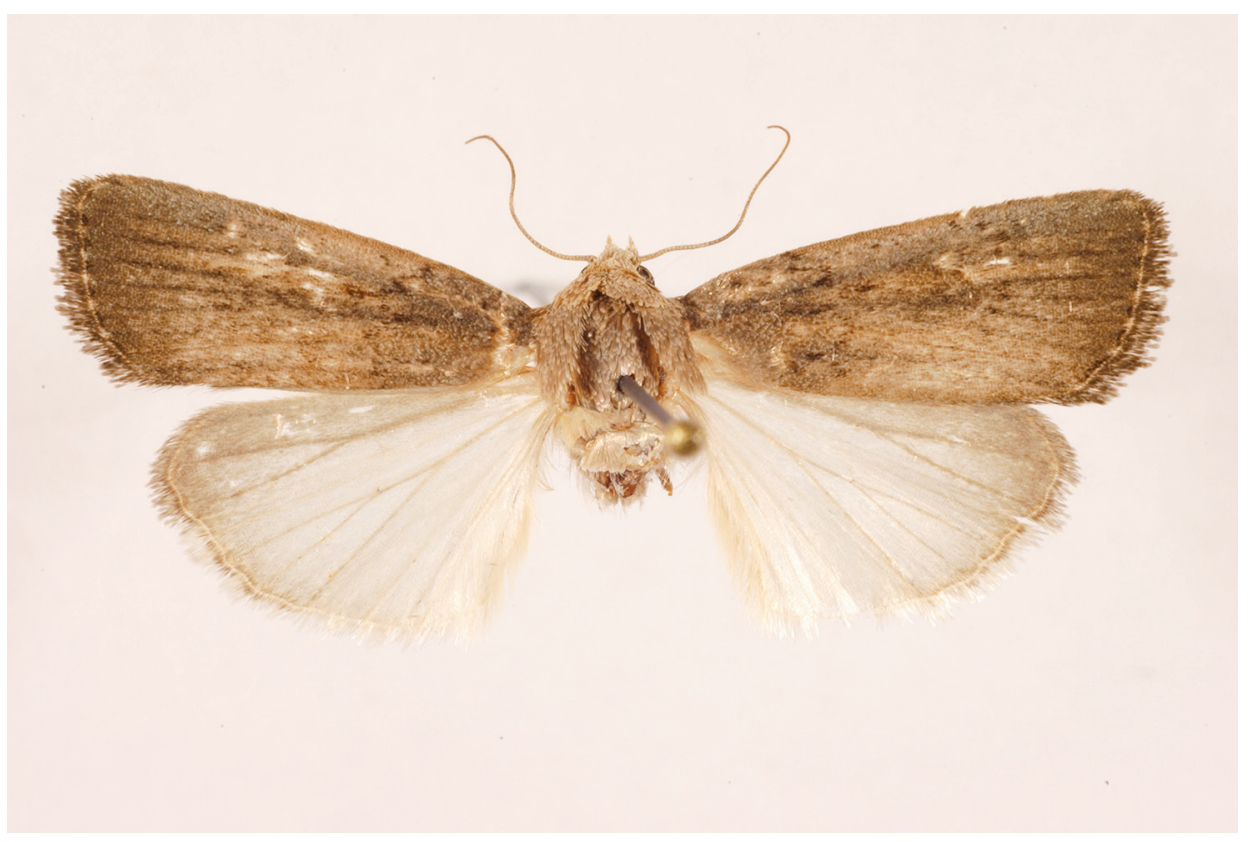

3. ábra: Athetis hospes nőstény, Magyarország, Oszkó, 2018.10.06. (Fotó Szeőke Kálmán)

elterjedésű faj jelen van Franciaországban, Spanyolországban, Portugáliában, Korzikán, Szardínián, Szicíliában, Olaszországban, Svájcban, Ausztriában, Bulgáriában, Albániában, Görögországban, Krétán, Horvátországban, Dániában, Németországban és Nagy-Britanniában. Európán kívül Törökországban és Észak-Iránban is észlelték. Észak-afrikai előfordulását HACKER (2001) közölte. Végül, újabb előfordulása vált ismertté Belgiumból (Prins, 2008) és Hollandiából (KuIJK \& AALMEKIndERS, 2008).

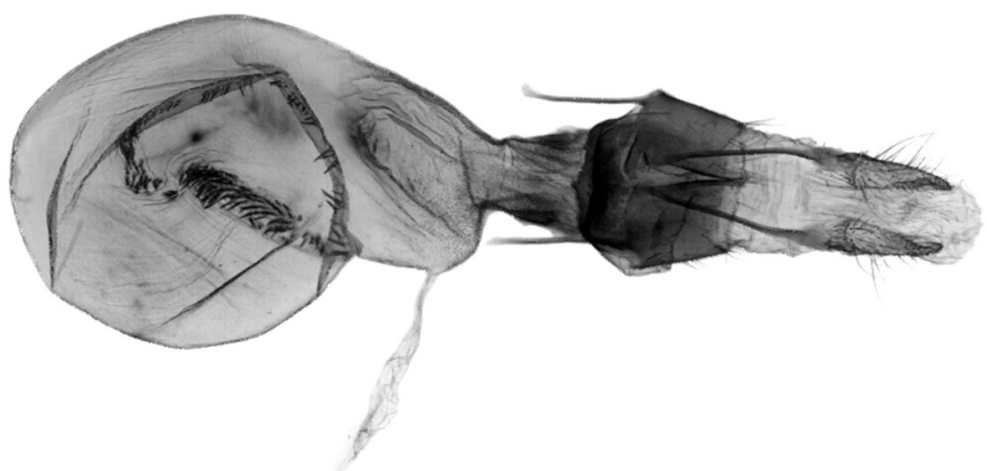

4. ábra: Athetis hospes nőstény genitália, Magyarország, Oszkó, 2018.10.06.

(Gen prep. et fotó Ronkay László) 
Magyarországhoz legközelebb Horvátországban és Szlovéniában található. Mivel az utóbbi években számos melegigényes, mediterrán faj jelent meg (és telepedett meg) Magyarországon, az Athetis hospes (Freyer, 1831) további, alkalmi megjelenése is várható. Meghonosodása ugyanakkor kérdéses, jóllehet ismert tápnövényei (Plantago, Epilobium, Nicotiana, stb.) Magyarországon is elöfordulnak.

Magyarország klímája az elmúlt évtizedekben melegedést mutat, mely egyes déli elterjedésü, melegigényes fajok felbukkanásának, gyakoribb előfordulásának kedvez.

Tipikusan kétnemzedékes lepkefaj. A lepke május-június, valamint augusztusszeptember (október) hónapokban repül. A nyári nemzedék hernyói július-augusztus hónapokban, a nyárvégi nemzedék hernyói áttelelve október-április hónapokban találhatók. A telelö hernyók hőigényét nem ismerjük, feltehetően melegigényesek, de legalább is mérsékelten hidegtürők. Ezért kérdéses, hogy a melegebb, hazai telek, hernyóik áttelelését lehetővé teszik-e?

A faj magyar nevének a „mediterrán selymes-bagoly” elnevezést javasoljuk.

\section{Köszönetnyilvánítás}

Köszönetünket fejezzük ki Ronkay Lászlónak, hogy a lepke genitália preparátumát és annak fényképét elkészítette és annak közléséhez hozzájárult. Ugyancsak köszönet illeti Ronkay Gábort, hogy e faj számos európai példányának általa készített fényképét a rendelkezésünkre bocsájtotta és közlésükhöz hozzájárult.

\section{Irodalom}

Abafi A. L. 1907: Magyarország lepkéi. Budapest, 137 pp.

Fibiger, M. \& Hacker, H. 2008: Amphipyrinae - Xyleninae. - Noctuidae Europaeae. Vol. 9. Entomological Press Soro, 410 pp. +12 color plates.

HACKER, H. 2001: Fauna of the Nolidae and Noctuidae of the Levante with descripcion and taxonomic notes. Esperiana 8: 1-315.

Karsholt, O. \& Razowski, J. 1996: The Lepidoptera of Europe Distributional. Apollo Books Stenstrup.

KovÁcs L. 1953: A magyarországi nagylepkék és elterjedésük. - Folia Entomologica Hungarica 6: 76-165.

Kovács L. 1956: A magyarországi nagylepkék és elterjedésük II. Folia Entomologica Hungarica 9: 89-140.

KuiJK, H. van, Aalmekinders, A. 2008: Athetis hospes een nieuwe soort voor Nederland (Lepidoptera, Noctuidae). - Entomologische Berichte, Amsterdam 68(3): 106-107.

Pastoralis G., Buschmann F. \& Ronkay L. 2016: Magyarország lepkéinek névjegyzéke. (Checklist of the Hungarian Lepidoptera) e-Acta Naturalia Hungarica 12: 1-258.

Prins,W. DE 2008: Proxenus hospes a new species for the Belgian fauna. (Lepidoptera, Noctuidae, Hadeninae) - Phegea 36(3): 99-100.

Spuler, A. 1910: Die Schmetterlinge Europas, 2 Stuttgart.

Varga Z., Ronkay L., Bálint Zs., László M. Gy., \& Peregovits L. 2004: A magyar állatvilág fajjegyzéke. (Checklist of the Fauna of Hungary), 3. kötet (Volume 3) Nagylepkék (Macrolepidoptera). Magyar Természettudományi Múzeum (Hungarian Natural History Museum) Budapest 1-111.

Warren, W. 1914: (In: Seitz) Gross-Smetterlinge der Erde. 